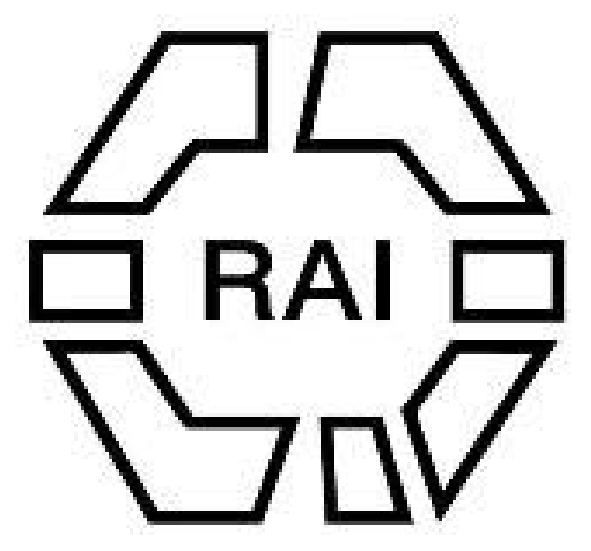

\title{
WILEY
}

\section{A'Kikuyu Fairy Tales (Rogano)}

Author(s): W. E. H. Barrett

Source: Man, Vol. 12 (1912), pp. 183-185

Published by: Royal Anthropological Institute of Great Britain and Ireland

Stable URL: http://www.jstor.org/stable/2787777

Accessed: 27-06-2016 02:36 UTC

Your use of the JSTOR archive indicates your acceptance of the Terms \& Conditions of Use, available at

http://about.jstor.org/terms

JSTOR is a not-for-profit service that helps scholars, researchers, and students discover, use, and build upon a wide range of content in a trusted digital archive. We use information technology and tools to increase productivity and facilitate new forms of scholarship. For more information about JSTOR, please contact support@jstor.org.

Royal Anthropological Institute of Great Britain and Ireland, Wiley are collaborating with JSTOR to digitize, preserve and extend access to Man 
*Batihh-nan sellē-r agidosir *batîh doro wērigi tijirsu(m). "Gerki urumeto, kal “wē!" Tir-gō(n). "Serē-m !" Esa(n). 'Tek-kō(n) ger-ked targi ēw mallēndigi *batīh-nan shalub-ir digdigosir, wētijirsu(m) “Ai jūrgi dogō-gettō(n) bi-tāri, kaligi “ ber wē !" Ikke wērosijir bōdin-gō(n) jürgi kulu wēr dogō-r tēbosirgi. "Wo! “ *batīh-nan tirtīchi!" Gan uwenga. Mangū-gō(n) tinna ēwigi noddijunduros bōdossa(n) sarki-ge(d). 'Tek-kō(n) abdogō-rtō(n) shugurigi tin dogō-r usūrgi wētijirsu(m) “Ar mallē werē galganosu." ${ }^{6}$ Ai-gō(n) tinnai yerin-gō(n) jurgi tāsi.

\section{Notes.}

${ }^{1}$ Eblisēn, for Arabic Abul Hussein, the fox.

${ }^{2}$ Gūlud, an earthenware jar, Arabic qullah.

${ }^{3}$ Torar-ki marosirgi, "unable to enter," and below kalar-ki ā-berikiru, "ye want to eat." Note the use of the verbal noun in -ar as an infinitive.

"Jelek ter man āgin, "thought it was the wolf." $C f$. ai jelek er man āgsi, "I thought you were the wolf."

${ }^{5}$ An dogo-r āg-usūru, "ye laugh at me," lit. "over me." Construction imitated from the Arabic, dahhaz aleh, "he laughed at him."

${ }^{6}$ The last sentence concludes nearly every Nubian narrative.

\section{Translation.}

There was a little fox, and he went down to the water to drink. Taking a pitcher to fill with water, and the pitcher being new, and the water reaching it, the pitcher made a noise (lit. wept). A wolf came, ran to seize the fox. The fox came running from fear and hid in a cave. And the wolf being unable to enter, went away. The fox (had) filled and carried his pitcher, and being new and the water reaching it, the pitcher wept in the cave. The fox thought it was the wolf and remained hidden ten days in the cave. And then he put his little head carefully out of the cave to see if the wolf was there or had gone. And seeing and knowing the wolf was not (there) he asked the pitcher, "Who are you that has frightened me? My faith, I " will bring you into the middle of the water and drown you."

Taking and fastening the pitcher to his tail, he went right into the water (lit., entered fording into the belly of the water) to drown the pitcher. And when the pitcher was filled with water, it broke his tail and sank. And the fox dripping blood came running up out. And the wolves and foxes saw him and laughed. He said, "Why " do ye laugh at me? I was eating my father's melons, and my tail broke from the " size of the melons. Come! ye want to eat, eat till you are full!" And they said, "It is good! come show us!" And he said, "It is good, come, be present!" And when they were come in the midst of the melons he gave them plump melons. "Do " not look behind you, eat." And they said "It is good!" And he coming from behind fastened everyone's tail to the stem of a melon, and said to them, "I will go " and come from above, eat, fill yourselves!" Saying thus he ran, went and stood on a hill. "O ! owners of melons."

And they breaking their tails ran from fear. And he descended from above and laughed at them and said, "We are all become like each other." And I was with them and went and came.

Another piece of folklore which has its parallel in Europe is the belief that the month of 'Tuba (January) borrowed from the month Ibshîr (February) (Coptic Amshîr) ten days of heat, giving in return ten days cold. One is reminded of "March said to "Averill, \&c., \&c."

G. W. MURRAY.

Africa, East.

Barrett.

A'Kikuyu Fairy Tales (Rogano). By Captain W. E. H. Barrett.

The Old Woman, Her Sons, and the Python.

A girl named Kasoni, on her way to get water for her father to drink, saw a large python basking in the sun near the path. The python had two mouths and 
its hair was beautifully arranged like that of a warrior. Kasoni stood and admired it for some moments. The python, seeing the girl looking at him, said, "I am " hungry; will you give me enough food to satisfy my hunger?" She replied, "Certainly I will; follow me to my village and I will give you as much as you can " eat." She then took up her water-gourd and proceeded in the direction of her home, followed by the python. Reaching the village she took it to a grain hut and invited it to eat. The monster put its head inside the hut and in a few minutes devoured all the contents. She then took it to another store, which it soon finished. Gradually it ate up all the grain in the village, but still was not satisfied. Kasoni then took it to the goat huts, and told it to eat them if it wished. One by one the goats were eaten, until none were left. The python then started eating the men, women, and children of the village, until Kasoni was the only one left. The monster asked her for more food, saying his hunger was not nearly satisfied. She replied that the only people of her village still left alive in addition to herself were a badtempered old woman, the wife of the Chief, and her two infant sons who lived in the forest, because the Chief would not allow his wife near him. "Well," said the python, "I will go and look for them, but will first eat you," saying which it opened one of its huge mouths and swallowed her at a gulp. It then went to search for the old woman and her children in the forest.

The woman, who was sitting near her hut, hearing a noise, looked up, and saw the monster approaching. Seizing both her children in her arms she fled and hid herself. The python searched for her for a long time, but not finding her went back to its abode. The old woman and her sons lived in the forest for many years, until the latter had grown into men. They one day asked their mother why it was that they were alone in the world and had no relations. She then told them the story of how the python had eaten up everybody in her village, but they laughed at her and said such a thing was impossible.

A few years after she had told them this story, she said to them one morning, "The time has now come for you to avenge the death of your father." She then told them to bring their swords, and taking them to a path near their hut, hid them in the bush close to the path, placing each about 100 yards from the other. Having done this she told them that she was going to call the monster who had destroyed their village, and instructed the younger that when he saw the monster come along he was to allow it to pass and not to strike until he saw his brother jump from his hiding place and strike it. She told the elder brother that as soon as the monster's head came near to him he was to rise at once and cut it off with his sword. She then went to the river and sang:-

"Evil one; you who ate up my people, and still were not satisfied, Come out of your resting place and I will give you a feast,

So plentiful is the food I have prepared that even you will hunger no more." Hearing her voice the python raised itself from the water and followed her. In a short time they passed the hiding place of the younger brother and soon came to that of the elder. The latter at once jumped up and eut the monster's head off with one blow of his sword, the former at the same time rose and cut off its tail. As soon as they had done this they heard a babel of voices calling out to them to strike no more, and to their amazement saw a large number of men, women, children, and goats emerge from the body of the dead python. One old man on seeing their mother, called her by name and asked her who these two bold warriors were who had reseued them from their enemy. She told him that they were his two sons who were small children on the day that he had been eaten by the monster.

Great rejoicings took place, and the chief at once set the people to work to rebuild their village and to make a large house for his wife, and one for each of 
his sons. All set to work with a right good will, and in a short period the village was as flourishing as it had ever been, and the old woman and her sons were ever afterwards treated with great respect.

W. E. H. BARRETT.

\section{Polynesia: Stewart's Island.}

Woodford.

Description and Names of various parts of a Canoe of Sikaiana or Stewart's Island. To accompany illustration. By Charles M. Woodford, C.M.G.

1. The outrigger

2. The three main bearers of outrigger platform

3. 'The squared plank on outrigger platform -

4. The five inner cross-pieces on platform -

5. The two outer cross-pieces on platform -

Te ama.

6. The three forked pieces fixing the outrigger to the three main bearers and to the two outer cross-pieces

7. The two single pieces fixing the outrigger to the central main bearer and to the two outer cross-pieces - - - - Te tugi.

8. The main canoe, hull, dug out of solid tree - - - - Te waka.

9. Forward - $\quad$ - $\quad$ - $\quad$ -

10. Aft

11. Amidships -

12. The stem and stern

- Amuri.

- Aloto.

- Tarapusi.

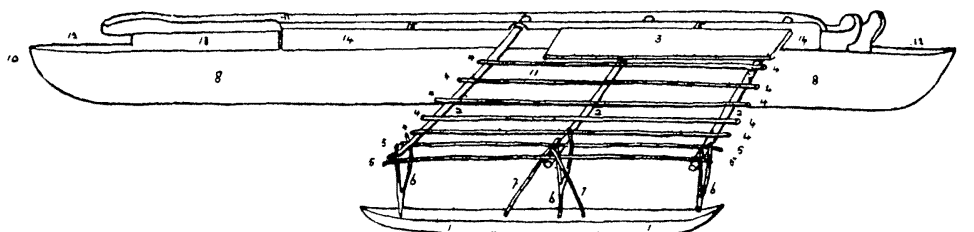

13. The after combing

14. The washboard

15. The chafing piece along top of washboard to protect it from the friction of the paddles -

16. The paddles

17. The paddle blade -

18. The paddle handle

19. The lashing twine, of cocoa-nut fibre

20. The oakum, for caulking seams

21. The baler -

22. The portside; away from the outrigger -

23. The starboard side; outrigger side -

24. The steersman

25. The paddlers, including the bow man when using the paddle

26. The bow man, when poling in shallow water

27. The tree, growing in bush, from which the hull is cut -

28. The tree, growing in bush, from which the bearers of platform (see No. 2) are made -

29. The tree, growing in bush, from which the cross-pieces of platform (see Nos. 4 and 5) are made -

30. The tree, growing on beach, from which the forked and straight sticks (see Nos. 6 and 7) are made
- Te pani.

Te borno.

Balama.

- 'Te hoi.

- Te lolo.

- Te kau.

- Wosana.

- Esula.

- Edata teriu.

- Gadea.

- Tama.

- Elula.

- Ealu.

- Etoko.

- Te pinipini.

Te salahalu.

- Te hau.

- Tauraura.

C. M. WOODFORD. 